PROGRAMA DE DOCTORADO EN FÍSICA

TESIS DOCTORAL:

Development of elastin-like recombinamers with increasing complexity and functionality from the molecular to the macroscopic scale

Presentada por Miguel González Pérez para optar al grado de Doctor por la Universidad de Valladolid

Dirigida por:

Prof. José Carlos Rodríguez-Cabello 
A mi familia 


\section{Agradecimientos}

Un largo camino lleno de grandes compañeros, bonitas experiencias y mucho esfuerzo podría asimilarse a lo que ha supuesto para mí realizar esta tesis. Esta etapa de mi vida no sólo me ha permitido conocer el mundo de la investigación si no también madurar y conocerme mejor a mí mismo. Nada de esto habría sucedido sin la posibilidad que me brindó Carlos en aquel mes de octubre de 2015 de poder formar parte del grupo BIOFORGE.

Por ello, en primer lugar, quiero dar la gracias a mi director de tesis, Carlos. Gracias por confiar en mí, por apoyarme en los momentos difíciles y por proporcionarme todos los medios y contactos imaginables que, sin duda, han enriquecido esta tesis en todos los sentidos.

Quiero continuar mi agradecimiento a Isra y Merche, que guiaron mis primeros pasos en el grupo y me ayudaron a entender las proteínas recombinantes como algo más que meros reactivos. Gracias también a Matilde, Javi, Alessandra, Luis, Irene, Menchu y Lubinda que siempre estuvieron allí para ayudarme y compartir momentos en estos años imborrables de laboratorio. Gracias a Miguel Ángel, Juan, Jorge, Óscar y Mar que poco a poco se fueron haciendo imprescindibles en mi paralela experiencia docente.

He de agradecer la suerte de tener unos grandes compañeros que han hecho de esta experiencia aún más enriquecedora. Gracias a Fernando, Marcos, Sergio, Doriana, Arturo, Juan, Soraya, Filippo, Sara, Irene, Leander, Tatjana, Sofía, Julio, Diana, Álvaro, Roci, Ana, Leticia, Sandra, Judyth, Sandra, Ito, Reinal, Mohamed, Alicia, Sergio, Mariángeles, Andrea, Eduardo, Ester, Tamara, Sofía, Elena, Diego, Carolina, Elisa, Santiago, Tomás, Laura, Nicola, Ilaira, Alessandra, Ozlem, Mónica, Carolina, Alicia, Teresa, Beatriz y Leticia. 
A Diego y su gran equipo de investigadores y profesionales, por su sonrisa e inmejorable acogida durante mis dos estancias en Québec. A mis amigos que me han apoyado durante esta etapa mucho más allá de la investigación. Y a mi familia que me ha acompañado y siempre ha creído en mí durante todos estos años. A todos, ¡muchas gracias! 
INDEX

1. ABSTRACT / RESUMEN ................................................. 10



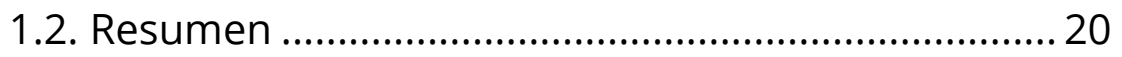





4. PUBLICATION 1: Tuning the Stiffness of Surfaces by Assembling Genetically Engineered Polypeptides with Tailored Amino Acid Sequence........................................... 44



5. PUBLICATION 2: Controlled Production of Elastin-like Recombinamer Polymer-based Membranes at a Liquidliquid Interface by Click Chemistry.................................... 48

5.1.1. Abstract. .48

6. PUBLICATION 3: Biocasting of an Elastin-Like Recombinamer and Collagen Bi-Layered Model of the Tunica Adventitia and External Elastic Lamina of the Vascular Wall 52

6.1.1. Abstract. .53

7. CONCLUDING REMARKS AND FUTURE DIRECTIONS .. 57

7.1. Genetic engineering, bioproduction and characterization of ELRs 59

7.2. Tuning the Stiffness of Surfaces by Assembling Genetically Engineered Polypeptides with Tailored Amino Acid Sequence. 60

7.3. Controlled Production of Elastin-like Recombinamer Polymer-based Membrane at a Liquid-liquid Interface by Click Chemistry 60 
7.4. Biocasting of an Elastin-Like Recombinamer and Collagen Bi-Layered Model of the Tunica Adventitia and External Elastic Lamina of the Vascular Wall ................... 61

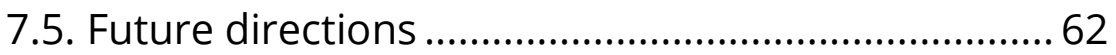

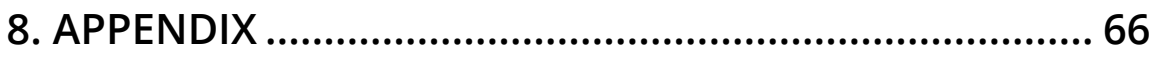

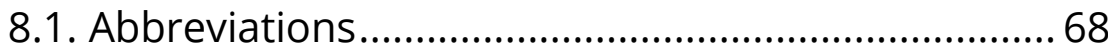

8.2. Amino acid nomenclature ........................................... 70

8.3. Author's contributions ................................................. 71

8.3.1. Publications ............................................................. 71

8.3.2. Conferences ........................................................... 73

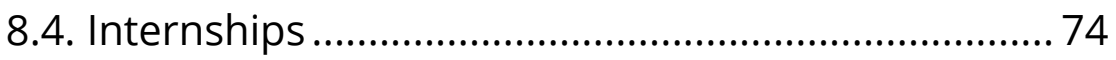

8.5. Review publication: Fibres from Elastin-Based Materials 74

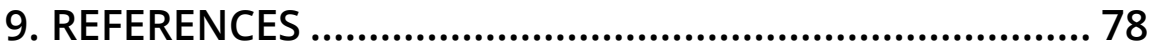

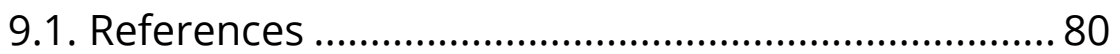




\section{ABSTRACT / RESUMEN}




\subsection{Abstract}

Unravelling the Nature machinery in the design and fabrication of supramolecular protein-based assemblies has continuously encouraged the research efforts into its imitation. Their morphological and biochemical uniqueness dictates not only the structural but also the biological functionalities of all living kinds. The unstoppable understanding on protein gene expression became a milestone in their replication, study and design for a myriad of applications.

In this light, bioinspired proteins have been genetically engineered by recombinant DNA technologies, being the elastin-like recombinamers (ELRs) a promising class of these biomaterials on itself. This family of polypeptides, consisting of a tandem repetition of the L-Val-L-Pro-Gly-X-Gly sequence, are designed to recapitulate the hydrophobic and intrinsically disordered regions found on the native tropoelastin. In such a way, their backbone preserves the transition temperature $\left(T_{\mathrm{t}}\right)$ or reversible lower critical solution temperature (LCST), the intrinsic biocompatibility and the native elastic recoil.

Their recombinant origin, along with their tailorable nature, facilitates to include extrinsic biofunctionalities, such as biodegradability, proangiogenesis, antimicrobial and cell-adhesiveness among others. This feature can be further exploited for tuning their intrinsic self-assembly response. Accordingly, physically and covalently crosslinkable domains together with specific block configurations can deviate the phase transition process guiding the assembling into a wide range of supramolecular structures with preeminent emerging properties.

The Publication 1 examines the assembly at the molecular level of two ELR models, i.e. the hydrophobic V84 and the amphiphilic EI, against $\mathrm{CH}_{3}, \mathrm{OH}, \mathrm{COOH}$ and $\mathrm{NH}_{2}$ decorated surfaces. The tetrakis (hydroxymethyl) phosphonium chloride 
(THPC) reactive group was further tethered to both polypeptide backbones and assessed its effect over the binding affinity. Quartz crystal microbalance with dissipation monitoring (QCM-D), multiparametric surface plasmon resonance (MPSPR) and atomic force microscopy (AFM) techniques revealed the different adsorption and conformation displayed by the studied ELR coatings. Whereas the V84 strongly bonded into hydrated and extended networks the EI arranged into more rigid and less dissipative coatings. The thickness of the deposited layers further identified the hydrophobic character and the effect of the tethered THPC groups, thus reporting a preferential affinity of both ELRs to the aliphatic $\mathrm{CH}_{3}$ and positively charged $\mathrm{NH}_{2}$ terminated substrates.

The Publication 2 focuses on the fabrication of micrometer-thick ELR-based membranes with adjustable thickness and diffusion properties at a liquid-liquid interface. Two click modified ELRs, namely the SKS-azide and the VKVcyclooctyne, were designed for being dissolved at room temperature in an aqueous or a water-immiscible organic phase, respectively. To prevent the phase transition of the SKS ELR serine amino acids were evenly interspersed along the polypeptide backbone. The polar character of the side hydroxyl groups conferred with a high transition temperature $\left(T_{\mathrm{t}}\right)$ to the ELR assuring its solvated state during the click crosslinking reaction and ELR membrane formation at the liquid-liquid interface. Complementarily, the cell-adhesive RGD tripeptide was genetically encoded in the SKS ELR to confirm the potential of the approach for fabricating membranes with customized bioactivity. Increasing the concentration of the employed recombinamers resulted in larger ELR membrane thicknesses and lower effective diffusion coefficients $\left(\mathrm{D}_{\mathrm{Eff}}\right)$. This parameter was evaluated employing Franz cell devices and FITC-dextran molecules ranging from 4 to $150 \mathrm{kDa}$. Recording in real 
time the events occurring at the interface allowed to study the formation process whereas environmental scanning electron microscopy (ESEM) offered a microscopic view of the ELR-based membranes on their hydrated state.

The last Publication 3 is dedicated to the development of a macroscopic bi-layered model of the external elastic lamina (EEL) and tunica adventitia of the vascular wall. A pair of ELRs, namely the RGD and the GTAR, were selected for recapitulating the EEL, while neonatal human dermal fibroblast (HDFn) embedded in reconstituted type I collagen served for replicating the tunica adventitia. Specifically, in order to enrich the bioactive character of the ELR layer, cell-adhesive domains were interspersed in the RGD ELR whereas proteolytic sequences were encoded in the GTAR. In addition, azide and cyclooctyne click crosslinkable groups were respectively tethered to the RGD and GTAR ELRs reinforcing the stability of the ELR layer in the construct. A cylindrical mold, containing a tubular mandrel in the center, was approached for the sequential fabrication of the two layers. This biocasting technique allowed to adjust the composition of the bi-layered construct thus reproducing the presence of elastin in the native tunica adventitia by the partial substitution of the collagen layer for a $30 \%$ in weight of ELR. In vitro maturation identified the favorable environment for the HDFn viability provided by the ELR and collagen as well as the HDFn-induced matrix remodeling over time. The found enhanced expression of glycosaminoglycan-rich extracellular matrix noted the differentiation of the embedded HDFn into myofibroblasts whereas the encoded cell attachment domains showed to promote the approximation of the embedded cells towards the inner ELR layer. The phase transition state of the ELR resulted in the formation of undulated morphological features and remarkable elastic properties once compared to the collagen. 
In summary, the works developed in this thesis provide new insights into the design and fabrication of novel structures with increasing complexity and functionality from ELRs. Specifically, it investigates the block structuration and noncovalent interactions role over the ELR assembly on functionalized surfaces at the molecular level, highlights the fabrication of micrometric ELR-membranes with adjustable diffusion properties at a liquid-liquid interface, and explores the ability to biocast a macroscopic bi-layered vascular wall model with tailored bioactivity that replicates the EEL and tunica adventitia in combination with HDFn and collagen type I.

\subsection{Resumen}

La compleja maquinaria empleada por la Naturaleza para el diseño y la fabricación de estructuras supramoleculares basadas en proteínas no ha hecho más que alentar los esfuerzos de investigadores para lograr su imitación. Su singularidad morfológica y bioquímica dicta no solo las funciones estructurales sino también las biológicas de toda clase de organismos vivos. El avance en el conocimiento sobre su expresión génica supuso un hito en su replicación, estudio y diseño para un amplio número de aplicaciones.

Recientemente, proteínas "bioinspiradas" han sido genéticamente diseñadas y fabricadas por tecnologías de ADN recombinante, siendo los recombinámeros de tipo elastina (ELRs) una clase prometedora de estos biomateriales en sí mismos. Esta familia de polipéptidos, que consiste en la repetición de la secuencia L-Val-L-ProGly-X-Gly, está diseñada para recapitular las regiones hidrofóbicas e intrínsecamente desordenadas de la tropoelastina. De esta manera, su estructura polipeptídica conserva la temperatura de transición $\left(T_{\mathrm{t}}\right)$ o temperatura crítica inferior de solución (conocida como "lower critical solution temperature" o "LCST"), la 
biocompatibilidad intrínseca y el comportamiento elástico de la elastina. Su origen recombinante junto con su naturaleza modulable facilita la inclusión de biofuncionalidades extrínsecas, tales como la biodegradabilidad, la angiogénesis, la adhesividad celular y la actividad antimicrobiana entre otras. Esta característica puede ser explotada aún más ajustando su respuesta intrínseca de autoensamblaje. En este sentido, dominios física y covalentemente entrecruzables junto con configuraciones modulares en bloque pueden desviar el proceso de separación de fases guiando la formación de una amplia gama de estructuras supramoleculares.

El Capítulo 4 examina la afinidad a nivel molecular de dos ELRs, el V84 con carácter hidrofóbico y el EI con carácter anfifílico, frente a superficies decoradas con los grupos $\mathrm{CH}_{3}, \mathrm{OH}, \mathrm{COOH}$ y $\mathrm{NH}_{2}$. El cloruro de tetraquis (hidroximetil) fosfonio (THPC) fue unido adicionalmente a ambos polipéptidos y se evaluó su efecto sobre la afinidad de adhesión. Las técnicas de microbalanza de cristal de cuarzo con monitoreo de la disipación (QCM-D), resonancia de plasmón superficial multiparamétrica (MP-SPR) y microscopía de fuerza atómica (AFM) revelaron la diferente adsorción y conformación mostrada por los recubrimientos de ELR. Mientras que el V84 mostró una fuerte adhesión formando redes hidratadas y extendidas, el EI dirigió la formación de recubrimientos más rígidos. El grosor de las capas depositadas permitió identificar la afinidad preferencial de ambos ELR modificados con THPC por los restos alifáticos $\left(\mathrm{CH}_{3}\right)$ y los sustratos terminados en $\mathrm{NH}_{2}$ cargados positivamente.

El Capítulo 5 se centra en la fabricación, en una interfaz líquida, de membranas micrométricas a base de recombinámeros de tipo elastina de espesor y propiedades de difusión controladas. Dos ELR modificados con grupos reactivos tipo “click", el SKS-azida y el VKV-ciclooctino, fueron diseñados para ser disueltos a temperatura 
ambiente en una fase acuosa o una fase orgánica inmiscible con el agua, respectivamente. Para evitar la transición de fase del ELR SKS aminoácidos de tipo serina fueron intercalados uniformemente a lo largo de la cadena principal del polipéptido. El carácter polar de los grupos hidroxilo confirió una temperatura de transición $\left(T_{\mathrm{t}}\right)$ elevada al SKS asegurando su estado hidrofóbicamente solvatado durante la reacción de entrecruzamiento "click" y la formación de la membrana de ELR en la interfaz líquida. De manera complementaria, el tripéptido RGD fue codificado genéticamente en el ELR SKS para confirmar la capacidad de la tecnología desarrollada para fabricar membranas con bioactividad personalizada. El aumento de la concentración de los recombinámeros empleados resultó en un incremento del espesor de la membrana y en una disminución de los coeficientes efectivos de difusión ( $\mathrm{D}_{\text {Eff }}$. Este parámetro fue evaluado empleando celdas de Franz y moléculas de dextrano marcadas con isotiocianato de fluoresceína (FITC) de pesos moleculares entre 4 y $150 \mathrm{kDa}$. La observación en tiempo real de la formación de la membrana en la interfaz líquida permitió estudiar el proceso de entrecruzamiento, mientras que la microscopía electrónica de barrido ambiental (ESEM) ofreció una visión microscópica de las membranas de tipo elastina en su estado hidratado.

El último Capítulo 6 está dedicado al desarrollo de un modelo bicapa macroscópico de la túnica adventicia y lámina elástica externa de la pared vascular. En este sentido, se seleccionó una pareja de ELRs, el RGD y el GTAR, para reproducir la lámina elástica externa, mientras que fibroblastos dérmicos humanos neonatales (HDFn) fueron embebidos en colágeno de tipo I para la replicación de la túnica adventicia. Específicamente, para enriquecer la respuesta bioactiva de la capa a base de ELR, dominios de adhesión celular fueron intercalados en el ELR RGD mientras que secuencias biodegradables fueron codificadas en el esqueleto del ELR 
GTAR. Además, los grupos entrecruzables de tipo click azida y ciclooctino se anclaron, respectivamente, a cada uno de los ELRs reforzando así la estabilidad de la capa en el constructo. Un molde cilíndrico, conteniendo un tubo de soporte en el centro, fue empleado para la fabricación del modelo bicapa. Esta técnica de bioconstrucción permitió ajustar la composición de las capas fabricando así un modelo conteniendo un 30\% en peso de ELR en la capa de colágeno que reproducía la presencia de elastina en la túnica adventicia. La maduración del constructo in vitro identificó la capacidad del ELR y colágeno para proporcionar un entorno favorable para la viabilidad de los HDFn, mientras que la evaluación por histoquímica reveló la remodelación de ambas capas y la expresión de una matriz extracelular rica en glicosaminoglicanos indicando la diferenciación de los fibroblastos en miofibroblastos con el tiempo. Los dominios de adhesión celular introducidos en el modelo demostraron promover la aproximación de las células embebidas hacia la capa de ELR interna, mientras que el estado de transicionado del ELR dio como resultado la formación de morfologías onduladas a la par que confirieron un predominante carácter elástico de la capa de ELR en comparación con la de colágeno.

En resumen, los trabajos desarrollados en esta tesis proporcionan nuevos conocimientos sobre el diseño y la fabricación de estructuras novedosas con una creciente complejidad y funcionalidad a partir de ELRs.

Específicamente, el trabajo desarrollado describe el papel de la estructuración en bloques y las interacciones no covalentes sobre el ensamblaje de las cadenas de tipo elastina frente a superficies funcionalizadas, destaca el hallazgo de una interfaz líquida para la fabricación de membranas micrométricas de tipo elastina con propiedades de difusión ajustables y el desarrollo de un modelo macroscópico bicapa 
con bioactividad personalizada que replica la túnica adventicia y lámina elástica externa en combinación con HDFn y colágeno de tipo I. 
2. INTRODUCTION 


\section{Introduction}

\section{Extracellular matrix proteins}

The extracellular matrix (ECM) is the natural bioscaffold of the human body [1]. Millions of years of evolution have enriched the heterogeneity and complexity of this non-cellularized network offering, nowadays, an extraordinary specialization from tissue to tissue. Water, along with proteoglycans and main fibrous proteins, including collagen, fibronectin, laminin and elastin, constitute this cell-secreted and regulated three-dimensional structure [2].

Proteoglycans consist of a protein backbone covalently decorated with long heteropolysaccharides termed as glycosaminoglycans (GAGs) [3]. These negatively charged and variable in composition macromolecules serve different structural and, more importantly, biological purposes. Their specific interplay with cells can determine from migration to proliferation, adhesion and differentiation responses, among others [2].

Collagen constitutes the most abundant interstitial ECM component $[4,5]$. Its predominating fibrillar architecture results from the repetition of the Gly-X-Y tripeptide, where the proline $(\mathrm{X})$ and hydroxyproline $(\mathrm{Y})$ residues occur with high frequency $[6,7]$. These polypeptide sequences, referred as $\alpha$ chains, arrange in the complete absence of intrachain hydrogen bonds into triple helices which, by the formation of interchain hydrogen and covalent lysyl oxidase (LOX) catalyzed bonds, coil together giving rise to the characteristic collagen fibrils [8].

Fibronectin also appears as long fibrils in the ECM. Secreted as a dimer, this disulfide stabilized molecules self-assemble into fibers from the nano up to the micro scale $[9,10]$. Its many binding sites interact with ECM proteins like collagen and 
participate, via integrin receptors [11], in the attachment, migration and differentiation of cells $[12,13]$.

Laminins arise from the triple-helical coiled-coil combination of $\alpha, \beta$ and $\gamma$ chains [14]. This particular assembly results into a variety of cross, $\mathrm{Y}$ and rod-shaped heterotrimer structures. Laminins further display intermolecular interactions with themselves as well as with other ECM components and cell surface receptors, thereby participating in the formation of ordered networks and in the biological signaling essential for the tissue development and functionality $[15,16]$.

Of special interest are the elastic fibers. These fibrillary structures, consisting of entangled microfibrils in crosslinked tropoelastin, confer with extensibility and elastic recoil to those tissues supporting repetitive stretching forces such as lungs, blood vessels, ligaments and skin [17]. Their resilience and elastic response derive from the ubiquitous composition and supramolecular self-assembly of the tropoelastin monomers into elastin [18].

Herein, bioinspired elastin-like polypeptides are investigated in order to exploit the structural, biological and mechanical features displayed by this unique ECM protein. In particular, we focus our work on the fabrication and study of novel elastinlike-based structures with tunable dimensions, morphologies, bioactivities and selfassembly properties.

\section{Elastin}

Elastin is a long-lasting ECM protein that constitutes the backbone of the elastic fibers. The remarkable low turnover, at the level of the human life expectancy [19], and resilient character of this protein results crucial for providing with structural support and elasticity to mechanically stressed tissues and organs [20]. 
Fabrication of functional elastic fibers is not trivial and requires from a defined number of spatiotemporal controlled stages. This process, known as elastogenesis $[21,22]$, begins with the secretion and coacervation, into 200-300 $\mathrm{nm}$ assemblies, of its precursor tropoelastin on the cellular surface. These structures grow and coalesce into micrometric spherules that, once transferred to the aligned microfibrillar templates found in the intercellular space [23], become covalent crosslinked by the LOX enzymes. The consolidation of this structure is undertaken by the repetition of these steps resulting in the maturation of the elastic fibers.

Tropoelastin is a $\sim 60 \mathrm{kDa}$ polypeptide defined by two opposite in hydrophilicity domains [24]. The hydrophobic regions consist of the repetition of glycine (Gly), Lvaline (L-Val), L-proline (L-Pro) and L-alanine (L-Ala) amino acids into di- to pentapeptides, i.e. GV, GVA, PGV, GGVP, GVGVP and GVGVAP. Whereas the hydrophilic regions display intermittent lysines (L-Lys) in L-alanine (KA) or Lproline-rich (KP) domains [25].

In solution, tropoelastin displays a $\mathrm{N}$-terminal coiled region from which a hinge and bridge depicting a foot (C-terminal) can be identified [26]. Each region plays a different role in the molecule. The $\mathrm{C}$ terminus contains the cell interacting sites, the $\mathrm{N}$ terminus confers the high elastic response while, the bridge between them, acts guiding the intermolecular self-assembly [27].

The elevated proportion of hydrophobic amino acids constituting the tropoelastin backbone impedes its direct interaction with water. Instead, clathrate-like water structures solvate them by hydrophobic hydration preventing them from selfaggregate [28].

Nevertheless, this thermodynamically stable state is compromised under physiological conditions. Temperature, along with $\mathrm{pH}$ and ionic strength, 
destabilizes the surrounding water cage triggering the endothermic hydrophobic selfassembly between the tropoelastin monomers [29]. Even though this coacervation process decreases the entropy of the protein this effect is overcompensated by the ordered water molecules, which become part of the bulk aqueous phase instead [30].

This coacervate consists of an undefined population of interchangeable structures. Herein, multiple local minima spots delimited by negligible barriers define the free energy landscape [31]. Even though the hydrophobic regions remain preferably hidden from the aqueous phase and the number of non-polar interactions is tripled in the coacervate, the formation of water-excluding cores and secondary structures is prevented by the characteristic glycine and proline content. The rigid proline residues confer conformational restrictions impairing the formation of stable secondary structures such as $\beta$-turns and $\beta$-sheets. On the other hand, the glycines introduce flexibility and favor the H-bond contacts with water, enlarging the hydration and the entropy change for the polypeptide chain to adopt organized structures [32].

Indeed, the intrinsic proline/glycine composition results determinant in the preservation of the highly hydrated state and affords a maximally-disordered state where solely transient and local secondary $\beta$-turn assemblies can coexist, acknowledging this state as a statistical coil [33]. This feature leads to classify the tropoelastin as an intrinsically disordered protein (IDP) and is the responsible for conferring the great flexibility and elasticity displayed by this polypeptide at the supramolecular scale [34].

\section{Elastin-like recombinamers (ELRs)}

Elastin-like recombinamers (ELRs) are a family of genetically engineered polypeptides inspired on the hydrophobic motifs of tropoelastin [35]. The replication of the consensus L-Val-L-Pro-Gly-X-Gly pentapeptide, where the guest residue in 
the fourth position can be any amino acid except proline, represents the most studied version. The use of DNA recombinant techniques [36] offers a powerful tool for their tailorable, reproducible and cost-effective production in organisms such as E. coli $[37,38]$.

Biochemical and physical properties of the native sequences are further preserved on these de novo synthetized polypeptides. As tropoelastin, ELRs offer a smart thermoresponsive behavior in water [39]. For a particular sequence, temperature defines a threshold from which ELR chains switch from an outstretched and hydrophobically hydrated state to an aggregate separated from the aqueous phase [40]. This temperature, known as transition temperature $(\mathrm{Tt})$ or lower critical solution temperature (LCST), acts disrupting the clathrate-like water structures hydrophobically hydrating the ELR backbone resulting in the increase of the system entropy [41]. Both extrinsic (including salts, pressure and $\mathrm{pH}$ ) and intrinsic factors (including polypeptide hydrophobicity and length) strongly affect the phase transition and so the ELR $T \mathrm{t}$ [42].

The reversible character of this response is further exploited for the purification of the ELRs giving rise to inverse transition cycling (ITC) techniques [43]. By means of temperature or salt concentration the bioproduced ELRs are dissolve or separate from the aqueous phase allowing the removal of the accompanying bacterial molecules lacking from this thermoresponsive and reversible phase transition.

The hydrophobically self-assembled ELR chains above the $T \mathrm{t}$ resemble the disordered structure of the tropoelastin in the coacervate [44, 45]. Herein, an undefined number of transient conformations, sparsely populated by appearing and disappearing secondary $\beta$-turns, define the ELR aggregate [46]. Indeed, this intrinsically disordered state arises from the content on proline and glycine domains. 
As previously described, the particular disposition of the proline (rigid) and glycine (flexible) residues restrict the formation of secondary structures while maintaining the coacervate in a highly hydrated and disordered state [32].

The aforementioned properties, form the intrinsic $T \mathrm{t}$ [42], to the self-assembly [47] and the bioactive responsiveness [48], can be finely tuned at the genetic level of their recombinant production. Such modifications, along with their inherent biocompatibility, make of these bioinspired polypeptides a novel source for the development of proteinaceous systems to be employed for basic research, drug delivery, tissue engineering and regenerative medicine [46].

\section{Design and study of novel structures with increasing complexity and}

\section{functionality from ELRs}

Nature has the ability to form extremely complex protein-based structures by the unlimited combination of 20 amino acids through the recurring amide bond [49]. Whereas a single type of link, namely the amide bond, can exist between the amino acid residues a large pool of intermolecular interactions appears orchestrating the self-assembly at the supramolecular scale [50]. As found, not only the structure is defined by the covalent and non-covalent interactions but the inherent and unique in vivo functionality as well [51]. In this light, the recombinant and tunable nature of the ELRs offers a powerful platform for the biomimicking, study and exploitation of this fascinating bottom-up self-assembly response [47].

\section{Surface functionalization and ELR interactions at the molecular level}

ELRs serve as a powerful tool for the biofunctionalization of materials. Thanks to their customizable proteinaceous backbone, covalent and physically crosslinkable domains can be tethered or encoded for their anchorage to the desired surface [52]. In this vein, ELR properties are transferred to the decorated substrate including from 
their intrinsic elasticity, thermo-responsiveness and biocompatibility [53], to genetically interspersed or covalently labelled bioactive domains [29].

Specifically, cell-adhesive [54-58], biomineralization [59, 60], non-thrombogenic [61-63], selective cell harvesting [64, 65] and antimicrobial coatings [66-68] have been developed from ELRs proving their potential on the functionalization of surfaces.

\section{Porous and tunable ELR-based hydrogels}

ELRs are a powerful source for the fabrication of highly porous, hydrated and biocompatible 3D scaffolds [69]. Physical and covalent crosslinking approaches enable the obtaining of these interconnected structures, termed as hydrogels [70]. Their similarity with the native ECM along with their inherent and tailorable bioactivity has made them extensively used for tissue engineering and regenerative medicine applications [71].

The intrinsic porous structure of the ELR-hydrogels not only guides the development of cells [72, 73] but holds great potential for controlling the transportation of molecules in liquid phases. However, this feature has been little explored [74], opening chances for the design of micrometer and robust ELRhydrogel structures with the adequate properties for controlling the diffusion of molecules in solution.

\section{Biomimicking vascular tissues form ELRs}

Elastin and collagen are the major components of the vascular ECM [75]. Both proteins are found distributed in concentric and tubular-like arrangements in presence of endothelial, smooth muscle and fibroblast cells [76]. The bioinspired ELRs can naturally replicate the functionality of the elastic fibers constituting this tissue. Indeed, their tunable nature can be exploited for the deployment of desirable 
vascular-like features such as cell-adhesiveness $[77,78]$ and biodegradability $[79$, 80].

Complementarily, covalent crosslinkable domains [81-83] could imitate the native crosslinked state of the elastin conferring with mechanical stability and elasticity to the tubular structure. Even though a number of vascular grafts have been developed from ELRs [84-89] no evidences of models concerning the use of ELRs for the recapitulation of the intricate vascular tissue can be found in the literature suggesting them as promising biomaterials in this field.

In conclusion, ELRs are exciting bioinspired scaffolds for functionalizing surfaces, developing diffusion systems and fabricating vascular wall models. Their recombinant origin and tunable character provide the means for controlling the selfassembling, morphological, diffusional, mechanical, and biological properties, from the molecular level to the macroscopic scale, providing access to novel structures with advanced complexity and functionality. 
3. OBJECTIVES 


\section{Objectives}

The main objective of this thesis is to engineer ELRs with increasing functionality and applicability from the molecular to the macroscopic scale. To address this purpose, we exploit the intrinsic biocompatibility and self-assembly response of these bioinspired polypeptides and complement them with the inclusion of noncovalent interactions, click crosslinkable and biologically active domains.

-The Publication 1 focuses on the generation of ELR designs with tunable assembling properties emerging form their amino acid sequence. For the study, mono- and di-block ELRs with different self-assembly responsiveness will be fabricated and decorated with tetrakis (hydroxymethyl) phosphonium chloride (THPC) reactive groups. Their affinity for aliphatic $\left(\mathrm{CH}_{3}\right)$, polar $(\mathrm{OH})$, and charged surfaces $\left(\mathrm{COOH}\right.$ and $\left.\mathrm{NH}_{2}\right)$ will be evaluated at the molecular scale by quartz crystal microbalance with dissipation monitoring (QCM-D) and multiparametric surface plasmon resonance (MP-SPR), whereas atomic force microscopy (AFM) will help unveiling the morphologies displayed by the self-assembled ELRs.

-In Publication 2 we address the fabrication and study of thin ELR-membranes with tunable diffusion properties comprising cell-adhesive domains. To address this, two ELRs will be designed for being dissolved at two immiscible, namely an aqueous and organic, liquid phases. Serine amino acids will be envisaged as the polar residues at charge of providing a high transition temperature to the ELR intended to be dissolved in the aqueous phase, while the RGD tripeptide will be encoded in the proteinaceous backbone to confer with cell-adhesiveness. Complementary and catalyst-free click crosslinkable groups will be tethered to the designed ELRs to obtain porous and highly hydrated interconnected networks in the micrometer range. The thickness, diffusion and mechanical properties of the ELR-based membranes 
will be controlled by selecting the concentration range, evaluating these properties by environmental scanning electron microscopy (ESEM), Franz cell devices and uniaxial test, respectively.

-Based on the previous experiences, in Publication 3 we aim at the development of a bi-layered model of external elastic lamina (EEL) and tunica adventitia of the vascular wall. In order to reproduce this complex and macroscopic structure, a hybrid construct comprising ELR and collagen will be envisaged. Two click crosslinkable ELRs, including cell-adhesive and biodegradable domains respectively, will be designed to replicate the EEL. Consecutively, type I collagen in combination with neonatal human dermal fibroblasts will be used for biomimicking the surrounding tunica adventitia layer. The mechanical properties, matrix remodeling and cell fate of the cellularized bi-layered model will be evaluated by tensile stress relaxation tests and histology during in vitro maturation at 3, 7 and 14 days. 


\section{PUBLICATION 1: Tuning}

\section{the Stiffness of Surfaces by}

\section{Assembling Genetically}

\section{Engineered Polypeptides with}

\section{Tailored Amino Acid Sequence}

Rui R. Costa, ${ }^{1,2}$ Miguel González-Pérez, ${ }^{3,4}$ Marcos Herrero-Gutiérrez, ${ }^{3,4}$ Ricardo

A. Pires, ${ }^{1,2,5}$ M. Alonso, ${ }^{3,4}$ J. Carlos Rodriguez-Cabello, ${ }^{3,4}$ Rui L. Reis, ${ }^{1,2,5}$ and Iva H. Pashkuleva $^{1,2}$

13B's Research Group, I3Bs-Research Institute on Biomaterials, Biodegradables and Biomimetics, University of Minho, Headquarters of the European Institute of Excellence on Tissue Engineering and Regenerative Medicine, AvePark, Parque de Ciência e Tecnologia, Zona Industrial da Gandra, 4805-017 Barco, Guimarães, Portugal

${ }^{2}$ ICVS/3B's, PT Government Associated Laboratory, Braga/Guimarães, Portugal ${ }^{3}$ G.I.R. Bioforge, University of Valladolid CIBER-BBN, Edificio LUCIA, Paseo de Belén, 19, 47011, Valladolid, Spain 
${ }^{4}$ Networking Research Center on Bioengineering, Biomaterials and Nanomedicine (CIBER-BBN), Valladolid, Spain

${ }^{5}$ The Discoveries Centre for Regenerative and Precision Medicine, Headquarters at University of Minho, Avepark, 4805-017 Barco,

Guimarães, Portugal

Biomacromolecules 2018, 19, 3401-3411. DOI: 10.1021/acs.biomac.8b00723.

\subsubsection{Abstract}

We introduce elastin-like recombinamers (ELRs) as polypeptides with precise amino acid positioning to generate polypeptide coatings with tunable rigidity. Two ELRs are used: V84-ELR, a hydrophobic monoblock, and EI-ELR, an amphiphilic diblock. Both were modified with the amine-reactive tetrakis (hydroxymethyl) phosphonium chloride compound. We evaluated the affinity, conformation, and dissipative behavior of ELRs assembled on alkanethiol self-assembled coatings by quartz crystal microbalance with dissipation monitoring, multiparametric surface plasmon resonance, and atomic force microscopy. The thickness of the polypeptide coatings showcases the preferential affinity of ELRs to $\mathrm{NH}_{2}$ - and $\mathrm{CH}_{3}$-terminated surfaces. We demonstrate that V84-ELR strongly bonded to the substrate and reorganizes into an extended and more hydrated layer as the adsorbed amount increases, whereas EI-ELR has a less dissipative behavior. The results suggest that ELR adsorption depends on the amino acid sequence and the substrate chemistry, ultimately influencing the stiffness of the polypeptide coatings. 


\section{PUBLICATION 2:}

\section{Controlled Production of Elastin-}

\section{like Recombinamer Polymer-}

\section{based Membranes at a Liquid-}

\section{liquid Interface by Click}

\section{Chemistry}

M. González-Pérez, ${ }^{1}$ I. González de Torre, ${ }^{1}$ M. Alonso, ${ }^{1}$ and J.C. RodríguezCabello $^{1 *}$

${ }^{1}$ BIOFORGE (Group for Advanced Materials and Nanobiotechnology), University of Valladolid, CIBER-BBN, Paseo de Belén 19, 47011 Valladolid, Spain.

Biomacromolecules 2020, 21, 10, 4149-4158. DOI: 10.1021/acs.biomac.0c00939.

\subsubsection{Abstract}

Diffusion of organic and inorganic molecules controls most industrial and biological processes that occur in a liquid phase. Although significant efforts have been devoted to the design and operation of large-scale purification systems, 
diffusion devices with adjustable biochemical characteristics have remained difficult to achieve. In this regard, micrometer-scale, bioinspired membranes with tunable diffusion properties have been engineered by covalent cross-linking of two elastinlike recombinamers (ELRs) at a liquid-liquid interface. The covalent approach selected provides the desired ELR-based membranes with structural support, and modulation of the concentration of the polypeptides employed confers direct control of the thickness, pore size, and diffusive properties over a broad range of molecular weights $(4-150 \mathrm{kDa})$. The recombinant and versatile nature of the proteinaceous building blocks employed further paves the way to engineering bioactive motifs within the membrane scaffold, thereby widening their applicability in the biological field. 


\section{PUBLICATION 3:}

\section{Biocasting of an Elastin-Like}

\section{Recombinamer and Collagen Bi-}

\section{Layered Model of the Tunica}

\section{Adventitia and External Elastic}

\section{Lamina of the Vascular Wall}

M. González-Pérez, ${ }^{1}$ D. B. Camasão, ${ }^{2}$ D. Mantovani, ${ }^{2}$ M. Alonso, ${ }^{1}$ and J. C. Rodríguez-Cabello ${ }^{1 *}$

${ }^{1}$ BIOFORGE (Group for Advanced Materials and Nanobiotechnology), University of Valladolid, CIBER-BBN, Paseo de Belén 19, 47011 Valladolid, Spain.

${ }^{2}$ Laboratory for Biomaterials and Bioengineering, Canada Research Chair I in Biomaterials and Bioengineering for the Innovation in Surgery, Department of MinMet-Materials Engineering, Research Center of CHU de Québec, Division of Regenerative Medicine, Laval University, Québec, QC Canada G1V 0A6.

Biomaterials Science, 2021, 9, 3860-3874. DOI: 10.1039/d0bm02197k 


\subsubsection{Abstract}

The development of techniques for fabricating vascular wall models will foster the development of preventive and therapeutic therapies for treating cardiovascular diseases. However, the physical and biological complexity of vascular tissue represents a major challenge, especially for the design and the production of off-theshelf biomimetic vascular replicas. Herein, we report the development of a biocasting technique that can be used to replicate the tunica adventitia and the external elastic lamina of the vascular wall. Type I collagen embedded with neonatal human dermal fibroblast (HDFn) and an elastic click cross-linkable, cell-adhesive and protease-sensitive elastin-like recombinamer (ELR) hydrogel were investigated as readily accessible and tunable layers to the envisaged model. Mechanical characterization confirmed that the viscous and elastic attributes predominated in the collagen and ELR layers, respectively. In vitro maturation confirmed that the collagen and ELR provided a favorable environment for the HDFn viability, while histology revealed the wavy and homogenous morphology of the ELR and collagen layer respectively, the cell polarization towards the cell-attachment sites encoded on the ELR, and the enhanced expression of glycosaminoglycan-rich extracellular matrix and differentiation of the embedded HDFn into myofibroblasts. As a complementary assay, $30 \%$ by weight of the collagen layer was substituted with the ELR. This model proved the possibility to tune the composition and confirm the versatile character of the technology developed, while revealing no significant differences with respect to the original construct. On-demand modification of the model dimensions, number and composition of the layers, as well as the type and density of the seeded cells, can be further envisioned, thus suggesting that this bi- 
layered model may be a promising platform for the fabrication of biomimetic vascular wall models. 
7. CONCLUDING REMARKS

AND FUTURE DIRECTIONS 


\subsection{Genetic engineering, bioproduction and characterization of}

\section{ELRs}

In this thesis, it has been shown the design, production, modification and characterization of a set of ELRs for the fabrication and study of novel structures with increasing complexity and functionality from the molecular to the macroscopic scale. In the Publication 1, a valine-inspired mono-block and an isoleucine and glutamic acid amphiphilic di-block, both containing a tandem of three lysines at their N-terminus, were biosynthetized and covalently conjugated with tetrakis (hydroxymethyl) phosphonium chloride (THPC). For the Publication 2, two ELRs were developed containing 24 lysine residues evenly distributed along the polypeptide backbone for the tethering of click crosslinkable groups further containing, one of them, RGD cell-adhesive domains and a population of serine amino acids for the increase of the $T_{\mathrm{t}}$. In the last Publication 3, a pair of bioactive ELRs, displaying cell-attachment and protease-sensitive sequences, were designed and conjugated with click reactive groups. Gene constructions codifying the employed ELRs were achieved and evaluated by agarose gel electrophoresis and DNA sequencing. ELRs were expressed in Escherichia coli as heterologous proteins and purified by ITC obtaining yields from 220 to $600 \mathrm{mg} \mathrm{L}^{-1}$ of culture media. Purity and monodispersity of the produced ELRs was confirmed by physicochemical characterization techniques. SDS-PAGE and MALDI-TOF techniques confirmed the purity and the theoretical molecular weight, respectively. HPLC demonstrated the correct amino acid composition and DSC assessed the $T_{\mathrm{t}}$ in aqueous phase. ${ }^{1} \mathrm{H}$ NMR and FTIR confirmed the purity and chemical modifications undertaken in the ELR's backbone. 


\subsection{Tuning the Stiffness of Surfaces by Assembling Genetically}

\section{Engineered Polypeptides with Tailored Amino Acid Sequence}

The ability of mono- and di-block ELRs for the assembling over different surfaces was evaluated at the molecular level. Specifically, the homogenous V84 and the amphiphilic EI ELRs were modified with tetrakis (hydroxymethyl) phosphonium chloride (THPC) and exposed to $\mathrm{CH}_{3}, \mathrm{OH}, \mathrm{COOH}$ and $\mathrm{NH}_{2}$ terminated surfaces. As examined by quartz crystal microbalance with dissipation monitoring (QCM-D) and multiparametric surface plasmon resonance (MP-SPR) the THPC-decorated ELRs resulted into a preferential binding affinity for the aliphatic and primary amine surfaces. Furthermore, in combination with atomic force microscopy (AFM), a soft and hydrated coating was identified for the mono-block V84. Conversely, the amphiphilic di-block EI exhibited a more rigid and oriented conformation. These observations suggested a fibrillar and a vesicular-like assembly behavior for the V84 and EI, respectively. This work provided new insights for the design of ELR-based coatings able to modulate the physicochemical properties of surfaces.

\subsection{Controlled Production of Elastin-like Recombinamer} Polymer-based Membrane at a Liquid-liquid Interface by Click

\section{Chemistry}

The fabrication of micrometer ELR-based membranes with diffusion properties and the capacity to include bioactive domains was explored at a liquid-liquid interface. Specifically, a pair of ELRs was designed, click modified and put in contact at the surface created between an aqueous and an organic water-immiscible phase. The crosslinking reaction was undertaken at room temperature, selecting the serine amino acid as the guest residue at charge of increasing the $T_{\mathrm{t}}$ and maintaining the ELR dissolved in the aqueous phase. Complementarily, the RGD sequence was 
included in the proteinaceous backbone confirming the ability to tailor the bioactivity of the engineered membrane on-demand. The study with concentration revealed a direct control over the thickness of the ELR-based membrane whereas scanning electron macroscopy (SEM) and uniaxial test to failure confirmed its porous microstructure and mechanical strength. Franz cell devices and FITC-dextran molecules ranging from 4 to $150 \mathrm{kDa}$ allowed to obtain the effective diffusion coefficients $\left(\mathrm{D}_{\mathrm{Eff}}\right)$ demonstrating the tunable diffusion properties of the membrane. The reported technology opens chances for the development of ELR-based diffusion systems with tunable shape, thickness and bioactiveness.

\subsection{Biocasting of an Elastin-Like Recombinamer and Collagen Bi-}

\section{Layered Model of the Tunica Adventitia and External Elastic}

\section{Lamina of the Vascular Wall}

A biocasting technique for fabricating a bi-layered model of the tunica adventitia and external elastic lamina (EEL) of the vascular wall was investigated from ELR and collagen type I. Two bioactive ELRs, incorporating cell adhesive and proteasesensitive sequences respectively, were selected for replicating the EEL. Complementarily, click reactive groups were tethered to both versions conferring with mechanical stability to the fabricated ELR layer. Surrounding, a type I collagen matrix cellularized with neonatal human dermal fibroblast (HDFn) was built for the recapitulation of the tunica adventitia. In vitro maturation confirmed the ability of the encoded cell-adhesive domains to promote the polarization of the embedded cells whereas the hydrophobically folded state of the ELR layer resulted in a wavy EELlike morphology after two weeks. Furthermore, the progressive compaction and remodeling of the collagen layer was confirmed, attributing this effect to the presumed differentiation of HDFn into myofibroblasts supported by the presence of 
glycosaminoglycans (GAGs), $\alpha$-smooth muscle actin ( $\alpha$-SMA) and focal adhesion kinase (FAK). Stress relaxation tests identified the predominant elastic character of the ELR layer resulting in outstanding elongation at break. The biocasting technique developed herein further permitted to tune the composition of the cellularized collagen layer thus fabricating a bi-layered model containing a 30\% of ELR by weight in the collagen gel. The developed technology was confirmed as a powerful tool for the fabrication of vascular wall replicas where the dimensions, cellular and extracellular matrix composition can be adjusted to demand.

\subsection{Future directions}

This thesis represents a small step forward in the exploration of the uncharted potential of ELRs. Every publication delves deeper into our knowledge of ELRs behavior and functionality from the molecular to the macroscopic scale. However, achieving the pursued goals does not suppose the end of this thesis purpose but only encourages our curiosity to continue developing ELR-based solutions in the Biomaterials science.

For example, the identified relationship between the ELR design and the selfassembly response onto a set of representative surfaces hold promises for functionalizing inactive or incompatible materials employed to design biomedical devices. As such, bioactive motifs can be genetically encoded in the tail of monoblock ELRs conferring the required physiological signaling upon implantation in living tissues. Alternatively, the hydrophobic core constituting the amphiphilic micelles assembled from ELR diblocks can serve for encapsulating hydrophobic compounds of interest for drug delivery applications.

The versatility of the fabricated ELR-based membranes, in terms of mechanical, diffusion, dimensions and bioactive properties envisions their potential 
specialization for tissue engineering applications. In particular, a system intended for healing cutaneous wounds and burns can be envisaged, including from cell-adhesive sequences to antimicrobial peptides.

On the other hand, the developed biocasting technique open chances for designing a complete replica of the vascular wall. Such biomimetic models may serve for investigating novel devices and therapies for cardiovascular diseases ex vivo as well as developing substitutes with great potential for regenerating damaged blood vessels and veins.

The ideas laid down in this section pretend to stimulate the curiosity of coming researchers who may develop new projects with the existing and the future techniques to come. Last but not least, this thesis intends to convey the importance of producing good science essential to the human fulfilment and the progress of society as a whole. 
8. APPENDIX 


\subsection{Abbreviations}

2,5-DHAP: 2,5-dihydroxyacetophenone

AA: Amino acid

AFM: Atomic force microscopy

ANOVA: Analysis of variance

$D_{\text {Eff: Effective diffusion coefficients }}$

DLS: Dynamic light scattering

DMEM: Dulbecco's Modified Eagle Medium

DNA: Deoxyribonucleic acid

DSC: Differential scanning calorimetry

ECM: Extracellular matrix

ECs: Endothelial cells

EDTA: Ethylenediaminetetraacetic acid

EEL: External elastic lamina

EGF: Epidermal Growth Factor

ELP: Elastin-like polypeptide

ELR: Elastin-like recombinamers

ESEM: Environmental scanning electron macroscopy

FBs: Fibroblast

FBS: Fetal bovine serum

FGFb: Fibroblast Growth Factor-basic

FTIR: Fourier Transform Infrared spectroscopy

GAGs: Glycosaminoglycans

H: Enthalpy

HDF: Human dermal fibroblast 
HDFn: Neonatal human dermal fibroblasts

HPLC: High-performance liquid chromatography

HUVECs: Human umbilical vein endothelial cells

IDP: Intrinsically disordered protein

IEL: Internal elastic lamina

ITC: Inverse transition cycle

ITT: Inverse temperature transition

LCST: Lower critical solution temperature

LOX: Lysyl oxidase

MALDI-TOF: Matrix-assisted laser desorption/ionization-time-of-flight

MMP: Matrix metalloproteinase

MP-SPR: Multiparametric surface plasmon resonance

MQ: MilliQ ultra-pure water

MW: Molecular weight

NMR: Nuclear magnetic resonance

OD: Optical density

PA: Plasminogen activator

PBS: Phosphate buffered saline

PdI: Polydispersity index

pKa: Dissociation constant of acids

$\mathrm{pKb}$ : Dissociation constant of bases

QCM-D: Crystal microbalance with dissipation monitoring

$\mathrm{R}_{\mathrm{H}}$ : Hydrodynamic radius

SDS-PAGE: Sodium dodecyl sulfate-polyacrylamide gel electrophoresis

SELR: Silk-elastin-like recombinamer 
SEM: Scanning electron microscopy

SMCs: Smooth muscle cells

TEM: Transmission electron microscopy

THPC: Tetrakis (hydroxymethyl) phosphonium chloride

$T \mathrm{t}$ : Transition temperature

S: Entropy

SAM: Self-assembled monolayer

SD: Standard deviation

SPAAC: Strain-promoted alkyne-azide cycloaddition

uPA: Urokinase plasminogen activator

Z-Pot: Zeta potential

\subsection{Amino acid nomenclature}

\begin{tabular}{|c|c|c|}
\hline Amino acid & $\begin{array}{c}\text { 3-letter } \\
\text { code }\end{array}$ & 1-letter code \\
\hline Alanine & Ala & A \\
Arginine & Arg & R \\
Asparagine & Asn & N \\
Aspartic acid & Asp & D \\
Cysteine & Cys & C \\
Glutamic acid & Glu & E \\
Glutamine & Gln & Q \\
Glycine & Gly & G \\
Histidine & His & H \\
Isoleucine & Ile & I \\
Leucine & Leu & L \\
Lysine & Lys & K \\
Methionine & Met & M \\
Phenylalanine & Phe & F \\
Proline & Pro & P \\
Serine & Ser & S \\
\hline
\end{tabular}




\begin{tabular}{|c|c|c|}
\hline Threonine & Thr & T \\
Tryptophan & Trp & W \\
Tyrosine & Tyr & Y \\
Valine & Val & V \\
Hydroxyproline & Hyp & Y \\
\hline
\end{tabular}

\subsection{Author's contributions}

\subsubsection{Publications}

Marija Stojic, Joaquín Ródenas-Rochina, María Luisa López Donaire, Israel González de Torre, Miguel González Pérez, José Carlos Rodríguez-Cabello, Lucy Vojtová, José Luis Jorcano, Diego Velasco. Elastin-Plasma Hybrid Hydrogels for Skin Tissue Engineering. Polymers 2021, 13(13), 2114. DOI: 10.3390/polym 13132114 .

Israel González de Torre, Miguel González-Pérez, Matilde Alonso, José Carlos Rodríguez-Cabello. Elastin-like Recombinamers (ELRs) for Biomedical Applications. Soft Matter for Biomedical Applications 2021, 205-235. DOI: 10.1039/9781839161124-00205.

José Carlos Rodríguez-Cabello, Israel González de Torre, Miguel GonzálezPérez, Fernando González-Pérez, Irene Montequi. Fibres from Elastin-Based Materials. Frontiers in Bioengineering and Biotechnology 2021, 9, 621. DOI: 10.3389/fbioe. 2021.652384 .

Miguel González-Pérez, Dimitria Bonizol Camasão, Diego Mantovani, Matilde Alonso, José Carlos Rodríguez-Cabello. Biocasting of an Elastin-Like Recombinamer and Collagen Bi-Layered Model of the Tunica Adventitia and External Elastic Lamina of the Vascular Wall. Biomaterials science 2021, 9, 3860-3874. DOI: 10.1039/d0bm02197k. 
Lubinda Mbundi, Miguel González-Pérez, Fernando González-Pérez, Diana Juanes-Gusano, José Carlos Rodríguez-Cabello. Trends in the Development of Tailored Elastin-Like Recombinamer-based Porous Biomaterials for Soft and Hard Tissue Applications. Frontiers in Materials 2021, 7:601795. DOI: 10.3389/fmats.2020.601795.

Constancio González-Obeso, Miguel González-Pérez, João F. Mano, Matilde Alonso, José Carlos Rodríguez-Cabello. Complex Morphogenesis by a Model Intrinsically Disordered Protein. Small 2020, 2005191. DOI: 10.1002/smll.202005191.

Miguel González-Pérez, Israel González de Torre, Matilde Alonso, José Carlos Rodríguez-Cabello. Controlled Production of Elastin-Like Recombinamer Polymer-Based Membrane at a Liquid-liquid Interface by Click Chemistry. Biomacromolecules 2020, 21, 10, 4149-4158. DOI: 10.1021/acs.biomac.0c00939.

Dimitria Bonizol Camasão, Miguel González-Pérez, Sara Palladino, Matilde Alonso, José Carlos Rodríguez-Cabello, Diego Mantovani. Elastin-Like Recombinamers in Collagen-Based Tubular Gels Improve Cell-Mediated Remodeling and Viscoelastic Properties. Biomaterials Science 2020, 8, 3536. DOI: $10.1039 / \mathrm{d} 0 \mathrm{bm} 00292 \mathrm{e}$.

Rui R. Costa; Miguel González-Pérez; Marcos Herrero-Gutiérrez; Ricardo A. Pires; Matilde Alonso; J. Carlos Rodríguez-Cabello; Rui L. Reis; Iva Pashkuleva. Tuning the Stiffness of Surfaces by Assembling Genetically Engineered Polypeptides with Tailored Amino Acid Sequence. Biomacromolecules 2018, 19, 3401-3411. DOI: 10.1021/acs.biomac.8b00723.

Miguel González-Pérez; José Carlos Rodríguez-Cabello. Polímeros Obtenidos mediante Tecnología Recombinante: Recombinámeros de Tipo Elastina. 
Revista de Plásticos Modernos 2018, 115, 7 - 14. Asociación para el Fomento de la

Ciencia y de la Técnica (FOCITEC), Madrid (España). ISSN 0034-8708.

\subsubsection{Conferences}

2019 - Gordon Research Conference on Elastin, Elastic Fibers and Microfibrils. Manchester, NH (USA). Oral and Poster Communication. Self-assembled silkelastin-like co-recombinamer into colporate particles.

2019 - Gordon Research Seminar on Elastin, Elastic Fibers and Microfibrils. Manchester, NH (USA). Poster Communication. Self-assembled silk-elastin-like co-recombinamer into colporate particles.

2019 - Tissue Engineering and Regenerative Medicine International Society (TERMIS)- EU Congress. Rhodes (Greece). Oral Communication. Formation of elastin-like recombinamer membranes in a two-phase system.

$2019-13^{\text {th }}$ International Symposium on Frontiers in Biomedical Polymers. Puerto de la Cruz (Spain). Oral Communication. Interface spontaneous membrane formation by two elastin-like recombinamers.

$2018-10^{\text {th }}$ European Elastin Meeting. Nijmegen (Netherlands). Oral Communication. Interface Tunable Elastin-Like Recombinamer Membranes.

2017 - International Symposium on Bioinspired macromolecular systems (ISBMS) Congress. Aveiro (Portugal). Oral and Poster Communication. Selforganized elastin-like recombinamer membranes.

$2017-2^{\text {nd }}$ Seminar of Young Researchers on Polymers. Madrid (Spain) Oral Communication. Self-assembled porous elastin-like membranes.

2017 - From 2D to 3D Scaffolding for Regenerative Medicine Workshop. Sedano (Spain) Oral Communication. Catalyst-free click gels as advanced systems for $3 D$ islet encapsulation. 


\title{
8.4. Internships
}

- 3 months internship at the Laboratory of Biomaterials and Bioengineering of the Universite Laval for the participation on the "Design and development of physiologically relevant cellularised scaffolds for vascular applications" project under the supervision of the Professor Diego Mantovani from the 10 of September to the 10 of December of 2019 in Québec, Canada.

- 3 months internship at the Laboratory of Biomaterials and Bioengineering of the Université Laval for the participation on the "Design and development of physiologically relevant cellularised scaffolds for vascular applications" project under the supervision of the Professor Diego Mantovani from the 10 of September to the 10 of December of 2018 in Québec, Canada.

\subsection{Review publication: Fibres from Elastin-Based Materials}

José Carlos Rodríguez-Cabello, Israel González de Torre, Miguel GonzálezPérez, Fernando González-Pérez, Irene Montequi.

BIOFORGE (Group for Advanced Materials and Nanobiotechnology), University of Valladolid, CIBER-BBN, Paseo de Belén 19, 47011 Valladolid, Spain.

Frontiers in Bioengineering and Biotechnology 2021, 9, 621. DOI:

\section{$\underline{10.3389 / \text { fbioe } .2021 .652384}$}

\begin{abstract}
Current cutting-edge strategies in biomaterials science are focused on mimicking the design of natural systems which, over millions of years, have evolved to exhibit extraordinary properties. Based on this premise, one of the most challenging tasks is to imitate the natural extracellular matrix (ECM), due to its ubiquitous character and its crucial role in tissue integrity. The anisotropic fibrillar architecture of the ECM has been reported to have a significant influence on cell behaviour and function. A
\end{abstract}


new paradigm that pivots around the idea of incorporating biomechanical and biomolecular cues into the design of biomaterials and systems for biomedical applications has emerged in recent years. Indeed, current trends in materials science address the development of innovative biomaterials that include the dynamics, biochemistry and structural features of the native ECM. In this context, one of the most actively studied biomaterials for tissue engineering and regenerative medicine applications are nanofiber-based scaffolds. Herein we provide a broad overview of the current status, challenges, manufacturing methods and applications of nanofibers based on elastin-based materials. Starting from an introduction to elastin as an inspiring fibrous protein, as well as to the natural and synthetic elastin-based biomaterials employed to meet the challenge of developing ECM-mimicking nanofibrous-based scaffolds, this review will follow with a description of the leading strategies currently employed in nanofibrous systems production, which in the case of elastin-based materials are mainly focused on supramolecular self-assembly mechanisms and the use of advanced manufacturing technologies. Thus, we will explore the tendency of elastin-based materials to form intrinsic fibers, and the selfassembly mechanisms involved. We will describe the function and self-assembly mechanisms of silk-like motifs, antimicrobial peptides and leucine zippers when incorporated into the backbone of the elastin-based biomaterial. Advanced polymerprocessing technologies, such as electrospinning and additive manufacturing, as well as their specific features, will be presented and reviewed for the specific case of elastin-based nanofiber manufacture. Finally, we will present our perspectives and outlook on the current challenges facing the development of nanofibrous ECMmimicking scaffolds based on elastin and elastin-like biomaterials, as well as future trends in nanofabrication and applications. 
9. REFERENCES 


\subsection{References}

1. Mouw, J.K., G. Ou, and V.M. Weaver, Extracellular matrix assembly: $a$ multiscale deconstruction. Nature Reviews Molecular Cell Biology, 2014. 15(12): p. 771-785.

2. Theocharis, A.D., et al., Extracellular matrix structure. Advanced Drug Delivery Reviews, 2016. 97: p. 4-27.

3. Iozzo, R.V. and L. Schaefer, Proteoglycan form and function: a comprehensive nomenclature of proteoglycans. Matrix Biology, 2015. 42: p. $11-55$.

4. Fratzl, P., et al., Fibrillar structure and mechanical properties of collagen. Journal of structural biology, 1998. 122(1-2): p. 119-122.

5. Ricard-Blum, S. and F. Ruggiero, The collagen superfamily: from the extracellular matrix to the cell membrane. Pathologie Biologie, 2005. 53(7): p. $430-442$.

6. Brodsky, B. and A.V. Persikov, Molecular structure of the collagen triple helix, in Advances in protein chemistry. 2005, Elsevier. p. 301-339.

7. Hulmes, D.J., Building collagen molecules, fibrils, and suprafibrillar structures. Journal of structural biology, 2002. 137(1-2): p. 2-10.

8. Molnar, J., et al., Structural and functional diversity of lysyl oxidase and the LOX-like proteins. Biochimica et biophysica acta (BBA)-proteins and proteomics, 2003. 1647(1-2): p. 220-224.

9. Davidson, L.A., R. Keller, and D.W. DeSimone, Assembly and remodeling of the fibrillar fibronectin extracellular matrix during gastrulation and neurulation in Xenopus laevis. Developmental dynamics: an official 
publication of the American Association of Anatomists, 2004. 231(4): p. 888895.

10. Larsen, M., C. Wei, and K.M. Yamada, Cell and fibronectin dynamics during branching morphogenesis. Journal of cell science, 2006. 119(16): p. 33763384.

11. Hynes, R.O., Integrins: bidirectional, allosteric signaling machines. cell, 2002. 110(6): p. 673-687.

12. Schwarzbauer, J.E. and D.W. DeSimone, Fibronectins, their fibrillogenesis, and in vivo functions. Cold Spring Harbor perspectives in biology, 2011. 3(7): p. a005041.

13. Pankov, R. and K.M. Yamada, Fibronectin at a glance. Journal of cell science, 2002. 115(20): p. 3861-3863.

14. Timpl, R. and J.C. Brown, The laminins. Matrix biology, 1994. 14(4): p. 275281.

15. Miner, J.H. and P.D. Yurchenco, Laminin functions in tissue morphogenesis. Annu. Rev. Cell Dev. Biol., 2004. 20: p. 255-284.

16. Mercurio, A.M. and L.M. Shaw, Laminin binding proteins. Bioessays, 1991. 13(9): p. 469-473.

17. Mithieux, S.M. and A.S. Weiss, Elastin, in Advances in protein chemistry. 2005, Elsevier. p. 437-461.

18. Muiznieks, L.D., A.S. Weiss, and F.W. Keeley, Structural disorder and dynamics of elastin. Biochemistry and Cell Biology, 2010. 88(2): p. 239-250.

19. Shapiro, S., et al., Marked longevity of human lung parenchymal elastic fibers deduced from prevalence of D-aspartate and nuclear weapons-related 
radiocarbon. The Journal of clinical investigation, 1991. 87(5): p. 18281834.

20. Green, E.M., et al., The structure and micromechanics of elastic tissue. Interface focus, 2014. 4(2): p. 20130058.

21. Gabriela Espinosa, M., et al., Elastic fibers and large artery mechanics in animal models of development and disease. Journal of biomechanical engineering, 2018. 140(2).

22. Nakamura, T., Roles of short fibulins, a family of matricellular proteins, in lung matrix assembly and disease. Matrix Biology, 2018. 73: p. 21-33.

23. Wagenseil, J.E. and R.P. Mecham, New insights into elastic fiber assembly. Birth Defects Research Part C: Embryo Today: Reviews, 2007. 81(4): p. 229240.

24. Wise, S.G. and A.S. Weiss, Tropoelastin. The International Journal of Biochemistry \& Cell Biology, 2009. 41(3): p. 494-497.

25. Bax, D.V., et al., Cell adhesion to tropoelastin is mediated via the C-terminal GRKRK motif and integrin $\alpha V \beta 3$. Journal of biological chemistry, 2009. 284(42): p. 28616-28623.

26. Baldock, C., et al., Shape of tropoelastin, the highly extensible protein that controls human tissue elasticity. Proceedings of the National Academy of Sciences, 2011. 108(11): p. 4322-4327.

27. Tarakanova, A., et al., Molecular model of human tropoelastin and implications of associated mutations. Proceedings of the National Academy of Sciences, 2018. 115(28): p. 7338. 
28. Miao, M., et al., Sequence and structure determinants for the selfaggregation of recombinant polypeptides modeled after human elastin. Journal of Biological Chemistry, 2003. 278(49): p. 48553-48562.

29. Ibáñez-Fonseca, A., et al., Trends in the design and use of elastin-like recombinamers as biomaterials. Matrix Biology, 2019. 84: p. 111-126.

30. Urry, D.W., The change in Gibbs free energy for hydrophobic association: Derivation and evaluation by means of inverse temperature transitions. Chemical physics letters, 2004. 399(1-3): p. 177-183.

31. Vindin, H., S.M. Mithieux, and A.S. Weiss, Elastin architecture. Matrix Biology, 2019.

32. Rauscher, S., et al., Proline and Glycine Control Protein Self-Organization into Elastomeric or Amyloid Fibrils. Structure, 2006. 14(11): p. 1667-1676.

33. Roberts, S., M. Dzuricky, and A. Chilkoti, Elastin-like polypeptides as models of intrinsically disordered proteins. FEBS Letters, 2015. 589(19PartA): p. 2477-2486.

34. Rauscher, S. and R. Pomès, Structural Disorder and Protein Elasticity, in Fuzziness: Structural Disorder in Protein Complexes, M. Fuxreiter and P. Tompa, Editors. 2012, Springer US: New York, NY. p. 159-183.

35. Acosta, S., et al., Elastin-Like Recombinamers: Deconstructing and Recapitulating the Functionality of Extracellular Matrix Proteins Using Recombinant Protein Polymers. Advanced Functional Materials. n/a(n/a): p. 1909050.

36. Rodríguez-Cabello, J.C., et al., Synthesis of Genetically Engineered Protein Polymers (Recombinamers) as an Example of Advanced Self-Assembled Smart Materials, in Nanotechnology in Regenerative Medicine: Methods and 
Protocols, M. Navarro and J.A. Planell, Editors. 2012, Humana Press: Totowa, NJ. p. 17-38.

37. Girotti, A., et al., Recombinant technology in the development of materials and systems for soft-tissue repair. Advanced healthcare materials, 2015. 4(16): p. 2423-2455.

38. Rosano, G.L. and E.A. Ceccarelli, Recombinant protein expression in microbial systems. Frontiers in microbiology, 2014. 5: p. 341.

39. Muiznieks, L.D., et al., Role of Liquid-Liquid Phase Separation in Assembly of Elastin and Other Extracellular Matrix Proteins. Journal of Molecular Biology, 2018. 430(23): p. 4741-4753.

40. Urry, D.W., et al., Hydrophobicity scale for proteins based on inverse temperature transitions. Biopolymers, 1992. 32(9): p. 1243-1250.

41. Rauscher, S. and R. Pomès, The liquid structure of elastin. eLife, 2017. 6: p. e26526.

42. Li, N.K., et al., Molecular Description of the LCST Behavior of an ElastinLike Polypeptide. Biomacromolecules, 2014. 15(10): p. 3522-3530.

43. Meyer, D.E. and A. Chilkoti, Purification of recombinant proteins by fusion with thermally-responsive polypeptides. Nature biotechnology, 1999. 17(11): p. $1112-1115$.

44. Muiznieks, L.D. and F.W. Keeley, Proline Periodicity Modulates the Selfassembly Properties of Elastin-like Polypeptides. Journal of Biological Chemistry, 2010. 285(51): p. 39779-39789.

45. Vindin, H., S.M. Mithieux, and A.S. Weiss, Elastin architecture. Matrix Biology, 2019. 84: p. 4-16.

46. !!! INVALID CITATION !!! 
47. Quintanilla-Sierra, L., C. García-Arévalo, and J.C. Rodriguez-Cabello, Selfassembly in elastin-like recombinamers: a mechanism to mimic natural complexity. Materials Today Bio, 2019. 2: p. 100007.

48. Flora, T., et al., Use of proteolytic sequences with different cleavage kinetics as a way to generate hydrogels with preprogrammed cell-infiltration patterns imparted over their given 3D spatial structure. Biofabrication, 2019. 11(3): p. 035008.

49. Chow, D., et al., Peptide-based biopolymers in biomedicine and biotechnology. Materials Science and Engineering: R: Reports, 2008. 62(4): p. $125-155$.

50. Zhou, H.-X. and X. Pang, Electrostatic Interactions in Protein Structure, Folding, Binding, and Condensation. Chemical Reviews, 2018. 118(4): p. $1691-1741$.

51. Aloy, P. and R.B. Russell, Ten thousand interactions for the molecular biologist. Nature Biotechnology, 2004. 22(10): p. 1317-1321.

52. Javier Arias, F., et al., Recent contributions of elastin-like recombinamers to biomedicine and nanotechnology. Current topics in medicinal chemistry, 2014. 14(6): p. 819-836.

53. MacEwan, S.R. and A. Chilkoti, Elastin-like polypeptides: Biomedical applications of tunable biopolymers. Peptide Science: Original Research on Biomolecules, 2010. 94(1): p. 60-77.

54. Castellanos, M.I., et al., Biofunctionalization of REDV elastin-like recombinamers improves endothelialization on $\mathrm{CoCr}$ alloy surfaces for cardiovascular applications. Colloids and Surfaces B: Biointerfaces, 2015. 127: p. 22-32. 
55. Salvagni, E., et al., A bioactive elastin-like recombinamer reduces unspecific protein adsorption and enhances cell response on titanium surfaces. Colloids and surfaces B: Biointerfaces, 2014. 114: p. 225-233.

56. García-Arévalo, C., et al., A comparative study of cell behavior on different energetic and bioactive polymeric surfaces made from elastin-like recombinamers. Soft Matter, 2012. 8(11): p. 3239-3249.

57. Costa, R.R., et al., Stimuli-responsive thin coatings using elastin-like polymers for biomedical applications. Advanced Functional Materials, 2009. 19(20): p. 3210-3218.

58. Straley, K.S. and S.C. Heilshorn, Design and adsorption of modular engineered proteins to prepare customized, neuron-compatible coatings. Frontiers in neuroengineering, 2009. 2: p. 9.

59. Li, Y., et al., Hybrid Nanotopographical Surfaces Obtained by Biomimetic Mineralization of Statherin-Inspired Elastin-Like Recombinamers. Advanced healthcare materials, 2014. 3(10): p. 1638-1647.

60. Vila, M., et al., 3D silicon doped hydroxyapatite scaffolds decorated with Elastin-like Recombinamers for bone regenerative medicine. Acta biomaterialia, 2016. 45: p. 349-356.

61. de Torre, I.G., et al., Elastin-like recombinamer-covered stents: Towards a fully biocompatible and non-thrombogenic device for cardiovascular diseases. Acta biomaterialia, 2015. 12: p. 146-155.

62. Putzu, M., et al., Elastin-like-recombinamers multilayered nanofibrous scaffolds for cardiovascular applications. Biofabrication, 2016. 8(4): p. 045009 . 
63. Woodhouse, K.A., et al., Investigation of recombinant human elastin polypeptides as non-thrombogenic coatings. Biomaterials, 2004. 25(19): p. 4543-4553.

64. Pierna, M., et al., Efficient cell and cell-sheet harvesting based on smart surfaces coated with a multifunctional and self-organizing elastin-like recombinamer. Biomacromolecules, 2013. 14(6): p. 1893-1903.

65. Flora, T., et al., Spatial control and cell adhesion selectivity on model gold surfaces grafted with elastin-like recombinamers. European Polymer Journal, 2018. 106: p. 19-29.

66. Atefyekta, S., et al., Antibiofilm elastin-like polypeptide coatings: functionality, stability, and selectivity. Acta Biomaterialia, 2019. 83: p. $245-256$.

67. Acosta, S., et al., Recombinant AMP/Polypeptide Self-Assembled Monolayers with Synergistic Antimicrobial Properties for Bacterial Strains of Medical Relevance. ACS Biomaterials Science \& Engineering, 2019. 5(9): p. $4708-4716$.

68. Acosta, S., et al., Antibiofilm coatings based on protein-engineered polymers and antimicrobial peptides for preventing implant-associated infections. Biomaterials Science, 2020.

69. Nettles, D.L., A. Chilkoti, and L.A. Setton, Applications of elastin-like polypeptides in tissue engineering. Advanced Drug Delivery Reviews, 2010. 62(15): p. 1479-1485.

70. Fernández-Colino, A., et al., Macroporous click-elastin-like hydrogels for tissue engineering applications. Materials Science and Engineering: C, 2018. 88: p. $140-147$. 
71. Varanko, A.K., J.C. Su, and A. Chilkoti, Elastin-Like Polypeptides for Biomedical Applications. Annual Review of Biomedical Engineering, 2020. 22(1): p. null.

72. Karageorgiou, V. and D. Kaplan, Porosity of 3D biomaterial scaffolds and osteogenesis. Biomaterials, 2005. 26(27): p. 5474-5491.

73. Loh, Q.L. and C. Choong, Three-dimensional scaffolds for tissue engineering applications: role of porosity and pore size. Tissue Engineering Part B: Reviews, 2013. 19(6): p. 485-502.

74. Mendoza-Meinhardt, A., L. Botto, and A. Mata, A fluidic device for the controlled formation and real-time monitoring of soft membranes selfassembled at liquid interfaces. Scientific Reports, 2018. 8(1): p. 2900.

75. Wagenseil, J.E. and R.P. Mecham, Vascular Extracellular Matrix and Arterial Mechanics. Physiological Reviews, 2009. 89(3): p. 957-989.

76. Mazurek, R., et al., Vascular Cells in Blood Vessel Wall Development and Disease. Advances in pharmacology (San Diego, Calif.), 2017. 78: p. 323350.

77. D'Souza, S.E., M.H. Ginsberg, and E.F. Plow, Arginyl-glycyl-aspartic acid (RGD): a cell adhesion motif. Trends in Biochemical Sciences, 1991. 16: p. 246-250.

78. Meiners, S. and M.L.T. Mercado, Functional peptide sequences derived from extracellular matrix glycoproteins and their receptors. Molecular Neurobiology, 2003. 27(2): p. 177-195.

79. Vassalli, J.-D., A. Sappino, and D. Belin, The plasminogen activator/plasmin system. The Journal of clinical investigation, 1991. 88(4): p. 1067-1072. 
80. Straley, K.S. and S.C. Heilshorn, Dynamic, 3D-Pattern Formation Within Enzyme-Responsive Hydrogels. Advanced Materials, 2009. 21(41): p. 41484152.

81. Krishna, U.M., et al., Hydrazone self-crosslinking of multiphase elastin-like block copolymer networks. Acta biomaterialia, 2012. 8(3): p. 988-997.

82. Madl, C.M., L.M. Katz, and S.C. Heilshorn, Bio-orthogonally crosslinked, engineered protein hydrogels with tunable mechanics and biochemistry for cell encapsulation. Advanced functional materials, 2016. 26(21): p. 36123620.

83. González de Torre, I., et al., Elastin-like recombinamer catalyst-free click gels: Characterization of poroelastic and intrinsic viscoelastic properties. Acta Biomaterialia, 2014. 10(6): p. 2495-2505.

84. Kumar, V.A., et al., Acellular vascular grafts generated from collagen and elastin analogs. Acta Biomaterialia, 2013. 9(9): p. 8067-8074.

85. Weber, M., et al., Multiple-step injection molding for fibrin-based tissueengineered heart valves. Tissue Engineering Part C: Methods, 2015. 21(8): p. $832-840$.

86. Putzu, M., et al., Elastin-like-recombinamers multilayered nanofibrous scaffolds for cardiovascular applications. Biofabrication, 2016. 8(4): p. 045009.

87. Caves, J.M., et al., The use of microfiber composites of elastin-like protein matrix reinforced with synthetic collagen in the design of vascular grafts. Biomaterials, 2010. 31(27): p. 7175-7182.

88. Mahara, A., K.L. Kiick, and T. Yamaoka, In vivo guided vascular regeneration with a non-porous elastin-like polypeptide hydrogel tubular 
scaffold. Journal of Biomedical Materials Research Part A, 2017. 105(6): p. $1746-1755$.

89. Fernández-Colino, A., et al., Small Caliber Compliant Vascular Grafts Based on Elastin-Like Recombinamers for in situ Tissue Engineering. Frontiers in Bioengineering and Biotechnology, 2019. 7(340). 
